$3(30) / 2015$

\author{
Dorota Klus-Stańska \\ Uniwersytet Gdański \\ klus_stanska@op.pl
}

\title{
Wyjść poza reżim imperatywu rozwojowego. Między inspiracjami Rousseau a wpływem myśli Foucaulta na współczesne studia nad dzieciństwem
}

\author{
Summary \\ Moving away from the regime of the developmental imperative. \\ Between the inspiration of Rousseau and the influence of the thinking of Foucault \\ on contemporary childhood studies
}

The text is an attempt at a comparative analysis of the concept by Rousseau in which he proposed moving away from the directive control of the development of the child, with those concepts that can be found in poststructural childhood psychology and pedagogy, whose authors are inspired by the work of Michel Foucault. The author reconstructs the incidents of the child's crying (Book 2) and child's agency (Book 3) described in "Emile", to show that Rousseau's proposition is, in reality, manipulative and oppressive in relation to the child, being as it is based upon the all-knowing mentor, who carries out his own hidden programme. The poststructural proposition frees childhood from the regime of standardization and normalisation, taking as its starting point a problematisation of so-called, scientific developmental psychology, questioning the very term development and the role of educational institutions. The fundamental difference between the concept of the right of the child to enjoy their life in freedom formulated by Rousseau and poststructuralist concepts, is identified by the author in terms of four areas: certainty "versus" the uncertainty of deciding(differences in status given to the thesis and the project, universalism "versus" localism (differences in scope of agreed upon understandings), binary "versus" diversity (differences in accepted ontological assumptions), instruction "versus" description (differences in moral attitude towards the child).

Słowa kluczowe: dziecko, dzieciństwo, studia nad dzieciństwem, rozwój, Rousseau, Foucault

Keywords: child, childhood, childhood studies, development, Rousseau, Foucault

\section{Sięgając współcześnie po Rousseau...}

W swoim artykule uwagę koncentruję na zagadnieniu rozwoju dziecka. Punktem wyjścia czynię tezę, zainicjowaną przez Rousseau, a współcześnie rozwiniętą i artykułowaną coraz wyraźniej, że rozwój jest nie tyle zjawiskiem, ile znaczeniem, jakie społecznie konstruujemy i nadajemy ludzkiej biografii, a zwłaszcza jej wczesnym etapom. Moim celem 
jest analiza podejść, w których dochodzi do problematyzacji zasadności odwoływania się do pojęcia rozwoju oraz do propozycji jego dekonstrukcji, przez wskazanie na zawartą w nim normalizującą opresywność 1 . Dla takiego ujęcia prace Rousseau i Foucaulta mogą stanowić dwie klamry spinające antyrozwojowy dyskurs, który rozpoczyna się na gruncie romantyzmu, a obecnie osadzony jest w poststrukturalnych rozpoznaniach polityczności wiedzy oraz przesunięć definicji prawdy z obszarów uniwersalizujących na lokalne (m.in. Freire 1975, 1983; Carr, Kemmis 1986; Witkowski, Giroux 2010). Choć zestawienie myśli Rousseau i Foucaulta nie jest oryginalne (por. np. Hicks 2004; Marshall 1996), wydaje się, że nie wyczerpało jeszcze swojego interpretacyjnego potencjału. Taki zabieg może być szczególnie znaczący na gruncie tego obszaru polskiej pedagogiki, która przyjmuje za centralny punkt swoich zainteresowań wczesny okres biografii człowieka, a więc w tym zakresie, w którym myślenie o rozwoju dziecka jest zdominowane dyskursem pomiarowym i wpisane w medykalizujący paradygmat psychologiczny. Dlatego też wskazanie punktów zbieżnych, ale i rozminięć na mapie refleksji nad zjawiskiem, które nazwałam reżimem imperatywu rozwojowego, w perspektywie rekonstrukcji inspirowanej ideami przenikającymi jedną z głośniejszych rozpraw Jana Jakuba Rousseau Emil, czyli o wychowaniu oraz krytycznej koncepcji normalizacji Michela Foucaulta, wydaje się obiecujące.

Wyrastający z myśli Rousseau naturalizm budowany jest przede wszystkim wokół dwóch wartości: wolności i natury. Wolność, w której Rousseau wyeksponował przede wszystkim jej negatywny aspekt jako wolności negatywnej, ,,wolności od”, miała w życiu dziecka najpełniej realizować się w warunkach oderwania od kultury, od presji wychowawczej, od przekazu społecznie podzielanej wiedzy. Ów swobodny rozwój można opisać słowami „poza edukacją”, gdzie element „poza” symbolizuje wyzwolenie.

Zaproponowana przez Rousseau idea towarzyszenia dziecku przez dorosłego, najpełniej wyrażona w dziele Emil, czyli o wychowaniu, jest silnie związana z jego koncepcją człowieka rozdartego między indywidualną egzystencją naturalną i kulturową egzystencją społeczną. Na poziomie antropologicznym Rousseau zakwestionował teleologiczne przesłanie o optymalnym stanie każdej rzeczy (Spaemann 2011: 123), twierdząc, że człowiek natury nie może być obywatelem, a obywatel nie może być człowiekiem naturalnym (Spaemann 2011: 124). Ów pełen napięcia dylemat w najmocniejszej postaci uwidacznia się podczas przechodzenia ze stanu dzieciństwa w stan dorosłości, stąd wynika potrzeba poszukiwania sposobu przełamania tego impasu, stąd też, jak pisze Spaemann: „Człowieczeństwo bez wewnętrznej sprzeczności - taki jest cel wychowania Emila” (2011: 121).

Próba zinterpretowania metody wychowania Emila (towarzyszenia Emilowi przez dorosłego) i odniesienia jej do myśli współczesnej napotyka na liczne przeszkody. Dziś wiemy na przykład, że wiele przekonań Rousseau na temat natury było wyidealizowanych lub po prostu fałszywych. Jego niewiedza w tym zakresie (usprawiedliwiona ogólnym stanem wiedzy jego epoki) staje się szczególnie widoczna podczas badań etologicznych nad zachowaniem zwierząt, żyjących przejściowo lub na stałe w strukturach opartych

\footnotetext{
1 Wątek problematyzacji kategorii rozwoju podejmuję też w innych tekstach (Klus-Stańska 2013; taż w druku, a; taż w druku, b).
} 
na więziach i relacjach społecznych (np. Jane Goodall, Vitus Droscher, Konrad Lorenz), a zwłaszcza prób rekonstrukcji zachowań dzieci z ewolucyjnego punktu widzenia (Renz-Polster 2012). Trzeba przy tym mieć świadomość, że błędy Rousseau w tym zakresie to bariera - chociaż ważna - jednak trywialna. Choć do metodyki zaleceń Rousseau należy z powodu zmiany wiedzy biologicznej, medycznej i psychologicznej podchodzić z krytyczną wrażliwością, nie zmienia to w istotny sposób głównego przesłania Emila.

Dużo bardziej kłopotliwe jest zrekonstruowanie rozumienia natury przez Rousseau, gdyż sama konstrukcja teoretyczna natury (również w sensie natury ludzkiej) jest w jego pracach bardzo złożona, niejednoznaczna, wpisana w konteksty etyczne i osobliwie związana z refleksją historiozoficzną (por. Baczko 2009: 51-146), mimo obietnicy, jaką składa na początku Emila, że określi ją ściśle (Rousseau 1955: 10). Dlatego w swoim tekście ograniczę się do otwarcia wybranych kwestii, które mogą być znaczące dla zrozumienia współczesnych krytycznych problematyzacji kategorii rozwoju, nie wchodząc w analizy pobocznych w tym wypadku napięć pojęciowych.

Rozwijany od pewnego czasu poststrukturalny dyskurs antyrozwojowy w teorii edukacji ma niewątpliwie swoje źródła także w myśli Rousseau. Szczególne znaczenie miało zakwestionowanie zasadności waloryzacji rozwoju, rozumianego jako postęp cywilizacyjny i biograficzne wrastanie jednostki w kulturę. Kluczowe również były takie elementy Emila, jak: wyeksponowanie fałszywości społecznej wiedzy na temat dzieci², aksjologiczna rehabilitacja zachowań dziecięcych ${ }^{3}$, budowanie wysokiego statusu swobodnego przeżywania dzieciństwa i prawa do aktywnego działania ${ }^{4}$, zgoda na gromadzenie przez dzieci niekierowanych doświadczeń jako podstawy własnej wiedzy o świecie ${ }^{5}$, czy - jak pisze B. Baczko - ,akcent na spontaniczną ekspresję kształtującej się w toku wychowania niepowtarzalnej osobowości” (Baczko 2009: 387).

Wizja dzieciństwa poza edukacją i ingerencją dorosłych nie przez wszystkich jest podzielana, bywa poddawana krytyce przez jej przeciwników, lub co najmniej spotyka się z zaleceniem ostrożności wobec - jak na przykład określa to J. Legowicz - bardziej po-

\footnotetext{
2 „Nie znamy zupełnie dzieciństwa: wobec błędnych na nie poglądów im dalej się zapuszczamy, tym bardziej błądzimy. (...) Zacznij więc od lepszego poznania swego ucznia, z największą bowiem pewnością, nie znasz go zupełnie” (Rousseau 1955: 4) lub „Nie umiemy nigdy postawić się na miejscu dzieci: nie wchodzimy w ich sposób myślenia i przypisujemy im swój własny; a idąc za biegiem własnych rozumowań wiążemy w ich głowach łańcuchami prawd jedynie szeregi bredni i błędów” (Rousseau 1955: 204).

3 „Ludzkość zajmuje właściwe sobie miejsce w porządku świata, tak jak dzieciństwo zajmuje swoje w porządku życia ludzkiego; trzeba widzieć w człowieku człowieka, a w dziecku dziecko" (Rousseau 1955: 69).

${ }^{4}$ „Nie należy nigdy trzymać dziecka na miejscu. O ile wola dzieci nie jest zepsuta z naszej winy, nie pragną one niczego na próżno. Powinny skakać, biegać, krzyczeć, kiedy mają ochotę. Wszelkie ich ruchy są potrzebą organizmu, który dąży do nabrania sił...” (Rousseau 1955: 79).

5 „Gorliwi nauczyciele, bądźcie prości, małomówni, powściągliwi, nie spieszcie nigdy z działaniem (...). Usuńcie jeżeli to możliwe, dobre wykształcenie, ażeby nie dać złego. (...) nie mogąc przeszkodzić dziecku w czerpaniu z przykładów, które widzi poza domem, ograniczcie czujność swoją do nadawania przykładom tym w jego umyśle odpowiednich dla tego umysłu form" (Rousseau 1955: 95-95).
} 
ezji niż filozofii zawartej w Emilu i braku doświadczenia praktycznego (Legowicz 1955: xxxi-xxxii).

Oponenci wskazują na zbytni optymizm pedagogiczny i radykalizm Rousseau. Dla kontrastu, który może ukazać potencjalnie interesującą - jak sądzę - perspektywę interpretacji wolnościowej koncepcji wychowawczej (czy, jak powiedzielibyśmy dzisiaj w nawiązaniu do nurtu antypedagogiki w pracach między innymi H. Schoenebecka (1994a; 1994b), na gruncie polskim najlepiej opracowanej przez B. Śliwerskiego (2007; por. też Szkudlarek, Śliwerski 1992), chcę wskazać na wybrane miejsca dysonansu, w których wolność dziecka zdaje się być w zaleceniach Rousseau ograniczana, zawężana, a nawet dławiona i to nie przez naturę, ale wychowawczo wdrożeniowe zachowanie dorosłego, jakie postuluje filozof. Innymi słowy, stawiam tezę, że w o ln o ść, j a k ą „o f e r u j e” Rousseau Emilowi, ma duży ładunek pozoru i podtrzymywanej przewagi dorosłego, który - może mniej jawnie, ale nadal z własnym projektem - podejmuje działania kształtujące wobec dziecka.

Snując historię Emila, Rousseau prowadzi szczegółowy wykład, sięgając zarówno po uogólnione argumenty, uzasadnienia i metafory, jaki i po liczne przykłady, konkretyzacje, analogie. Jego praca, poddana hermeneutycznemu oglądowi, pozwala uruchomić bogaty wachlarz interpretacji i odsłon, zarówno tych, które ze sobą korespondują i współgrają, jak i takich, które pozostają wobec siebie dynamicznie kontrowersyjne, czy wręcz sprzeczne. To właśnie w tych sprzecznościach i potencjalnie odmiennych odczytaniach Emila można odnaleźć pole dla bardziej szczegółowych odniesień ze strony współczesnych studiów nad dzieciństwem i dyskursu antyrozwojowego.

\section{Między dziecięcą zależnością i silą}

Dla poszukiwania tych odniesień i inspiracji wybrałam dwa fenomeny, silnie charakteryzujące psychospołeczne funkcjonowanie dziecka. Są to: płacz (przynależny do sfery emocjonalnej) i poczucie sprawczości (odnoszące się do sfery działaniowej). Oba one są przez Rousseau włączane także w obszar spontanicznie podejmowanego poznania, gdyż - opisując je - zawsze odcina się od zasady pouczania i wyjaśniania, opowiadając się za naturalnymi konsekwencjami, które pozwalają dziecku uczyć się samemu.

\section{Płacz}

Począwszy od przedmowy do „Emila”, płaczowi Rousseau poświęca sporo miejsca, czyniąc z niego punkt wyjścia życia dziecka, pierwszy język używany w budowaniu kontaktów społecznych $\mathrm{i}-\mathrm{w}$ zależności od stopnia opanowania „skłonności do płaczu” przez dziecko - wskaźnik sukcesu lub porażki działań wychowawczych. O płaczu Rousseau pisze między innymi, analizując wejście w drugi okres życia (1955: 65): „Skoro tylko dzieci zaczynają mówić, płaczą rzadziej. Postęp ten jest naturalny; jeden język zastępuje drugi. Skoro tylko mogą wypowiedzieć słowami, że cierpią, po cóż miałyby wypowiadać 
to krzykiem. Chyba że boleść zbyt jest żywa, by słowo mogło ją wyrazić. Jeżeli wtenczas płaczą w dalszym ciągu, to winni są ludzie, którzy je otaczają. Skoro tylko Emil wypowie: boli mnie, trzeba będzie najdotkliwszych boleści, żeby go zmusiły do płaczu.

Jeżeli dziecko jest wątłe, wrażliwe, jeżeli krzyczy bez rzeczywistego powodu, usuwam powód jego krzyku; w ten sposób, że czynię go bezskutecznym. Dopóki płacze - nie dochodzę doń. Biegnę - gdy tylko ucichnie (...)".

Pomijam tu kwestie uproszczeń na temat ekspresji emocji, roli płaczu w życiu emocjonalnym człowieka i budowaniu społecznych relacji - bo, co oczywiste, były one tworzone w klimacie epoki ${ }^{6}$. Współcześnie rozumiemy je inaczej ${ }^{7}$, ale to rozumienie było w czasach Rousseau nie do odkrycia. Zauważmy jednak wyraźne atrybuty normalizacyjne - jeśli normalizację zdefiniować w zgodzie z koncepcją Foucaulta - ukryte w tym fragmencie. Przede wszystkim kontekst sytuacyjny (tu: stany i zdarzenia, które mogą być dla dziecka trudne lub bolesne i usprawiedliwiać jego gwałtowne emocje) zostaje odgórnie i jednoznacznie zdefiniowany przez dorosłych. To oni, zdaniem Rousseau, jasno wiedzą, czy istnieje cośr z e c z y w i ś c i e niepokojącego, czy nic takiego się nie dzieje, czy jest jakiś r z e c z y w is ty powód do płaczu, czy też dziecko demonstruje niczym nieusprawiedliwione roszczenia. Zachowanie dziecka, które dorosły uznaje za nieadekwatne do przyjętych przez siebie definicji sytuacji, które wymagają interwencji (np. sakramentalne „dostał jeść i nie ma mokro"), jest wygaszane zgodnie z - jak dziś można przyjąć - racjonalnością behawiorystyczną („Dopóki płacze - nie dochodzę doń. Biegnę - gdy tylko ucichnie”).

Rousseau nie tylko wyłącznie dorosłym przypisuje kompetencję, którą można określić jako „posiadanie racji” i mocy poprawnych rozpoznań, eliminując sens prób zrozumienia sygnałów dziecka, ale formułuje też stanowcze argumenty w modelu normalizacji dwubiegunowej, stanowiącej rodzaj matrycy, która - z zawartymi w niej wzorami zachowań przypisanych kolejnym etapom życia dziecka - wyklucza różnorodność i bogactwo indywiduów, a w to miejsce dookreśla „dziecko normalne”. W tym przypadku emiliański egzemplaryzm, oparty na deklarowanej idei oddania Emilowi prawa do wolności i swobodnego życia, paradoksalnie konstytuuje model dziecka znormalizowanego.

6 Tego rodzaju przekonania mają ogromną siłę przetrwania. W 1926 r. w Stanach Zjednoczonych wydano oficjalne oświadczenie, zgodnie z którym „Rodzice nie powinni ulegać płaczącemu dziecku, żeby się nie nauczyło, że zawsze dostaje to, czego się domaga", uzupełnione przez komentarz Amerykańskiego Ministerstwa Pracy następującej treści: Postępując w ten sposób, można wychować sobie domowego tyrana, który przez swoją roszczeniowość zrobi z matki niewolnicę" (za: Renz-Polster 2012: 165).

7 Choć nie mam w sobie optymizmu H. Renz-Polstera co do powszechności przyjmowanych współcześnie koncepcji wychowawczych, jednak na przykład z perspektywy ewolucyjno-biologicznej „Dzisiaj skłaniamy się raczej ku temu, by wierzyć małym ludziom” (Renz-Polster 2012: 165), gdyż „Z punktu widzenia teorii sygnałów, niemowlęta płaczące bez powodu popełniałyby błąd. Ich postępowanie nie byłoby warte ponoszonych strat" (Renz-Polster 2012: 168), na przykład w formie wydatkowanego wysiłku, który trzeba następnie skompensować. Jeśli odwołać się do koncepcji przywiązania Bowlby’ego (2007) - inspirowanej w znacznym stopniu ewolucjonistyczną biologią, etologią, a także psychologią poznawczą i systemową teorią kontroli - łatwa dostępność osób, do których dziecko jest przywiązane i ich niezmienna gotowość do udzielania pomocy jest podstawowym warunkiem redukowania niepokoju dziecka i budowania relacji społecznych opartych na zaufaniu. 
Normalizacji podlega również metoda. Nie jest ona otwartym, dialogicznym byciem z dzieckiem, gdyż postulowane przez Rousseau działanie dorosłego ma swój jasno określony cel. Traktowana jest jako jedynie słuszna i nacechowana krytycznym odrzuceniem innych - określanych w całym wywodzie przez Rousseau jako „powszechnie stosowane” - strategii. Swoją krytyczność wobec innych metod autor Emila opiera na bezdyskusyjnie przyjmowanym przez siebie przekonaniu, że dają się one zastąpić nowym i - jak to wartościująco określa - „roztropnym” - jak to określa - postępowaniem dorosłego.

Z taką identyfikacją zaleceń Rousseau koresponduje do pewnego stopnia interpretacja dokonana przez B. Baczko, który jednak nie dostrzega tu możliwości kwestionowania samego dyskursu rozwojowego. Pisze on o dorosłym występującym w Emilu: „Niezmiernie charakterystyczne jest przy tym, że mentor, który interweniuje w proces kształtowania się osobowości, pozostaje cały czas czynnikiem zewnętrznym wobec tego procesu. Wychowawca nie uczy się w toku procesu wychowywania - z góry wie on wszystko i przewiduje wszystko" (Baczko 2009: 387-388).

Podstawą narracji w Emilu jest ostra krytyka rozwoju rozumianego jako wrastanie jednostki w zdobycze cywilizacyjne, możliwie szybka internalizacja wzorców i norm kulturowych i porzucenie swojej natury na rzecz - powiedzielibyśmy dziś - socjalizacji. Problematyzacji rozwoju, a zwłaszcza krytyce jednego z jego modeli, towarzyszy stanowcze wskazanie drogi alternatywnej, zdaniem Rousseau - jedynej prawidłowej. Dodam, że dla tej drugiej drogi konstruuje on szczegółowe oprzyrządowanie met o d y c z n e: dostarcza dziesiątek wskazówek, rad, sugestii, przykładów. Formułowany przez niego wymóg powstrzymywania się dorosłych/ nauczycieli od interwencji wychowawczych jest przekuwany na rozbudowany rezerwuar zasad i posunięć, którym Rousseau nadaje status jedynie słusznych.

Mamy tu zatem dwie strony modelowego zachowania dorosłych wobec dzieci: $\mathrm{z}$ jednej, Rousseau, zarzucając nam (poniekąd chyba bardzo słusznie), nieznajomość dzieci, czyni z obserwacji ich w warunkach pozostawienia im swobody działania podstawowe narzędzie odejścia od fałszywych mniemań (co czyni z dziecka niezależny podmiot relacji społecznych z dorosłymi). $Z$ drugiej: Rousseau przyjmuje jako bezsporny obraz tego, jakie dzieci $s q$, jakie - pod pewnymi względami - powinny pozostać, a jak - pod innymi - powinny się zmieniać.

Krytykując nasycony kulturowo model rozwoju, w to miejsce przedstawia własny. Przez fakt wyprowadzenia go z tego, co nazywa naturą człowieka - u n i w e r s a li z u j e go totalnie.

\section{Poczucie sprawstwa}

Drugi fenomen, który wybrałam do analizy, to poczucie sprawstwa. Rzecz jasna, tak określone - w opisie wychowania Emila nie mogło wystąpić. Łączę je z przywoływaniem przez Rousseau sytuacji, które przypominają jeden z konfliktów rozwojowych wskazywanych przez Erika Eriksona (2004), polegający na napięciu między autonomią a wstydem i zwątpieniem, gdy dziecko, chcąc decydować o sobie i kontrolować własne życie 
napotyka na reakcje otoczenia, które mogą pozwolić mu doświadczać poczucia wpływu i autonomii lub skazują na umacnianie zwątpienia i bezradności.

Rousseau aprobuje i zaleca dziecięce sprawstwo wobec świata materialnego, choć nie jest to aprobata czyniona $\mathrm{z}$ rozmachem. Wskazuje na prawo dzieci do samodzielnego badania elementów świata i eksperymentowania z nimi z uwagi na konieczność rozbudzania ciekawości poznawczej dzieci (tutaj sprawstwo traktowane jest instrumentalnie), ale też łączy idee samodzielnego dziecięcego działania $\mathrm{z}$ warunkami do doznawania kar naturalnych (wynikających z osobistego zderzenia z prawami natury), a więc także z tymi sytuacjami, w których dziecko przekonuje się, że lepiej czasem nie starać się być sprawcą jakichś okoliczności. Kary naturalne są jednak ważnym elementem ludzkich doświadczeń, przyczyniają się do konstruowania wiedzy i jako takie stanowią dobry element komplementarny do sukcesu jako skutku działań sprawczych.

Nie ulega wątpliwości, że otworzył on przestrzeń samodzielności dzieci i ich prawa do inicjowania własnych doświadczeń; pisał wszak: „Mamy słabość pedantyczną i szkolarską do uczenia dzieci tego, czego nauczyłyby się lepiej same" (1955: 66), manifestując $w$ ten sposób pierwszeństwo tzw. kar naturalnych. Bez wątpienia także zakładał, że „... każde działanie ma być manifestacją wewnętrznej potrzeby jednostki” (Baczko 2009: 387). Jednak przy boku Emila niemal stale obecny jest nauczyciel; nawet wobec miłości Emila Rousseau daje nauczycielowi prawo manipulacji, którą nazywa roztropnością.

A jeśli spojrzymy na sprawstwo jako prawo do decydowania o własnym życiu, wyrażające się między innymi w doświadczaniu własnego wpływu społecznego, sytuacja się komplikuje. Odnosząc się do odczuwania przez dziecko własnych możliwości i mocy Rousseau pisze: ,postępuj z uczniem według jego wieku. Osadź go przede wszystkim na właściwym miejscu i utrzymaj go na nim tak, żeby nie usiłował go opuścić. (...) Nie nakazuj mu nigdy nic, zupełnie nic. Nie pozwól mu nawet wyobrazić sobie, że przypisujesz sobie jakąś władzę nad nim. Niechaj wie tylko, że jest słaby, a ty - silny i że skutkiem twojego i swojego położenia jest $\mathrm{z}$ konieczności zdany na twoją łaskę; niech to wie, niech się tego nauczy, nich to czuje (...)” (1955: 87). I dalej: „niech wszystkie twoje odmowy będą nieodwołalne; niech wypowiedziane »nie« będzie spiżową ścianą, przeciw której jeżeli pięć, sześć razy załamie się jego siła, nie będzie więcej usiłował jej obalić. W ten sposób czynisz go cierpliwym, równym, poddającym się losowi (...)" (1955: 87).

Taki obraz konfrontacji woli dziecka $\mathrm{z}$ wolą dorosłych nie jest u Rousseau wpisany w ideologię hierarchicznego autorytetu i władzy, ale raczej wyrasta z romantycznej koncepcji Ja. Sam Foucault dokonał interpretacji tej koncepcji. Odczytując jego myśl Gutman (1988) utrzymuje, że zdaniem Foucaulta Rousseau pisał w języku wczesnych koncepcji ja (self), nie lokując ich we współczesnych modelach relacji władzy. Jednak jego zasadniczy wkład w dostrzeżenie „,Zwykłej” jednostki polegał na wprowadzeniu jej do języka; powołał ją w ten sposób niejako do życia obok istniejącej do tej pory jednostki - bohatera, wybitnej indywidualności (Gutman 1988: 99-120).

Uznając zasługi Rousseau dla konstrukcji zindywidualizowanej koncepcji ,ja”, trzeba jednak zauważyć, że na poziomie operacjonalizacji relacji z dzieckiem doprowadza on 
do zmaterializowania relacji między ludźmi i samych ludzi w niej biorących udział. O ile słynna rada Rousseau, żeby dziecko przybliżyć do jabłka, a nie jabłko do dziecka, by je nauczyć, że rzeczom nie można rozkazywać, jest przyrodniczo uzasadniona i daje też lekcję działania, o tyle niemożność wywarcia jakiegokolwiek perswazyjnego wpływu na drugiego człowieka, czyni z niego materiał nieludzki, a relację pozbawia aksjologicznie rozumianego upodmiotowienia. Jedna ze stron tej relacji (dziecko) zostaje pozbawiona praw sprawczych i usytuowana na pozycji „niemej”, w określony sposób uargumentowanej antropologicznie (,normalna” relacja „,normalnego” dorosłego z dzieckiem, które „roztropnie normalizujemy”).

Tak w odniesieniu do płaczu, jak i sprawstwa Rousseau deklaruje atencję dla naturalnej dobroci dziecka, zaufanie do jego potrzeb i instynktów oraz dbałość o jego swobodę. Deklaracje te od chwili ich formułowania wsparte na przebijającej tekst potrzebie podkreślania swojej unikatowości, wyjątkowości i odmienności od innych: „Pisząc, nie opieram się na poglądach cudzych, ale na własnych. Widzę rzeczy inaczej niż inni ludzie...” (Rousseau 1955: 4-5). To poczucie wyższości, które daje się obserwować w postaci nieprzyjemnej dominanty w „Wyznaniach” (Johnson 1988). To samo poczucie wyższości zdaje się przenikać relację Emil i mentor, powołany do życia narracją w pierwszej osobie. Mentor musi być górą. Jest inny niż inni nauczyciele /dorośli /ludzie; jest jedyny w swoim rodzaju, a w każdym razie stale o tej wyjątkowości od tego, „co powszechne” mówi, a przecież nie jest w stanie nie odgrywać pierwszorzędnej roli, okazywać się tym, który wie, przewiduje, panuje nad sytuacją.

Dlatego trudno jednoznacznie rozstrzygnąć, czy propozycja Rousseau okazuje się w ten sposób jedynie wewnętrznie sprzeczna, czy również dobrze oddaje napięcie, jakie musiało przenikać ówczesną próbę głoszenia emancypacji dzieci. Radykalnemu zerwaniu z tradycyjnym rozumieniem dziecka jako wymagającego karząco-moralizujących działań o charakterze korekty i interwencji, towarzyszy w Emilu program uodpornienia na cierpienie, któremu Rousseau nadaje kluczowe egzystencjalne znaczenie, oraz swoista koncepcja niezbędnej skuteczności dorosłego, którą udało się przełamać dopiero kontynuatorom idei naturalizmu, a której odrzucenie musiało czekać, by na gruncie pedagogiki poststrukturalnej otrzymać mocniejsze uzasadnienie teoretyczne.

\section{Ku współczesnym kontrowersjom wokół rozwoju}

Radykalizm współczesnej problematyzacji kategorii rozwoju na gruncie pedagogiki ma dziś swoje dwa powiązane ze sobą źródła, dla których byłoby możliwe poszukiwanie paraleli z myślą Jana Jakuba Rousseau. Jednym z nich są inspirowane krytyką kolonializmu i postkolonializmu antropologiczne teorie post-rozwojowe (post-development theory), nazywane także anty-rozwojowymi (anti-development theory). Zakwestionowano w nich monopol północno-zachodnich, etnocentrycznych koncepcji rozwoju kulturowego i ekonomicznego, oraz prawomocność nadawania im statusu uniwersalnych. Natomiast drugim kluczowym źródłem stała się psychologia krytyczna, w której sformułowano tezy, 
które wydają się reakcją na długotrwałą dominację paradygmatu pomiarowego (Klus-Stańska 2013).

Pojęcie rozwoju, dobrze dotychczas umocowane nie tylko w koncepcjach medykalizujących, ale również w społecznym myśleniu, i niekwestionowane, ukazane zostało jako nieoczywiste, skonstruowane kulturowo i kolonizujące nasze myślenie o najwcześniejszym okresie życia, a w teoriach psychologiczno-edukacyjnych dyskursywne, nadużywane i potencjalnie opresyjne. Jego problematyczność, wskazana radykalnie w pracach psychologów krytycznych, staje się punktem wyjścia dla poszukiwania nowych paradygmatów studiów nad dzieciństwem i nowych form relacji dziecko-dorosły w instytucjach edukacyjnych. Główne pytanie zatem nie brzmi, jak zapewniać odpowiedni rozwój dziecka, ale czy w ogóle należy mówić o rozwoju.

W semantykę rozwoju wpisany jest fenomen zmiany. Ale orientacje antyrozwojowe nie kwestionują wartości zmiany jako takiej. Pozostaje ona naturalnym i żywotnym elementem życia społeczeństw i jednostek. Jednak traci te swoje rysy, które w tzw. Świecie Mniejszości (Minority World), zostały uznane jako jej nieodzowne atrybuty, nadające zmianie status rozwojowy. Należą do nich przede wszystkim takie cechy, jak: analityczność, klasyfikacja i planowość określana w logice skuteczności. Jak podkreśla A. Escobar (1991), planowanie rozwoju okazuje się problemem nie tylko na obszarach, gdzie nie udaje się osiągnąć jego celu, ale również tam, gdzie się go osiąga.

Model rozwoju przyjmowany zarówno w polityce, ekonomii, jak też w psychologii, pedagogice $\mathrm{i}$ innych przestrzeniach życia społecznego i nauki, został umocowany autorytetem ekspertów, co nadało mu status Prawdy i Słuszności. Dokonana w ten sposób uniwersalizacja modelu rozwoju doprowadziła do eliminacji głosu Świata Większości (Majority World), definiując wszystko, co nie spełniało arbitralnie wyznaczonych standardów jako nierozwinięte, czy niedorozwinięte lub nienormalne. To na przykład dlatego o dziecku, które nie daje się skonstruować jako „the organization child” (Moss-Kanter 1972) i które w przedszkolu jest nieszczęśliwe, smutne, płacze, wycofuje się z aktywności, nie mówimy, że jest nieszczęśliwe, smutne, płacze, wycofuje się z aktywności, ale mówimy, że jest nieprzystosowane.

Nie podejmuję tu krytyki kapitalizmu, artykułowanej w dyskursie antyrozwojowym (bo z wieloma jej tezami się nie zgadzam). Chcę natomiast zwrócić uwagę na konsekwencje, jakie wynikają z podważenia planowania rozwoju i zapewniania jakości jako zasadniczych, jedynie słusznych, czy choćby tylko najbardziej wartościowych na gruncie psychologii i pedagogiki, a także z dekonstrukcji koncepcji linearnego rozwoju przebiegającego w określonych stadiach.

To właśnie, jak sądzę, w tym punkcie zwrotu w myśleniu o dziecku znajduje się najbardziej wrażliwy obszar konfrontacji russoistycznej koncepcji wychowania Emila z koncepcją zmian zachodzących w człowieku artykułowanych dziś z inspiracji myśli Foucaulta i innych eksponujących rozproszenie ,,prawd” o istocie i sensie edukacji. 
Naturalizm Rousseau bywał najczęstszym przywołaniem i argumentem w dwubiegunowym konflikcie między pajdocentryzmem i didaskalocentryzmem. Z większą precyzją ów spór został określony przez L. Kohlberga i R. Mayer (1993), przez uzupełnienie go o progresywizm jako ideologię w pewien sposób przełamującą krańcowość obu pozostałych orientacji. Dokonali oni również identyfikacji teorii psychologicznych, leżących u podstaw każdej z ideologii, więżąc naturalistyczny romantyzm $\mathrm{z}$ teoriami stadialnego dojrzewania (np. z Freudem), transmisję kulturową z behawioryzmem, a progresywizm $\mathrm{z}$ teoriami psychologii poznawczej (zwłaszcza z Piagetem).

Zarówno na gruncie teorii edukacji, jak i psychologii od dawna toczyła się batalia o koncepcję człowieka i jego rozwoju. Pedagogika zorientowana humanistycznie szczególnie podejrzliwie podchodziła do behawioryzmu jako odbierającemu jednostce ludzkiej jej człowieczeństwo, znacznie lepiej traktując dwa pozostałe nurty wraz z ich psychologicznym oprzyrządowaniem. Jednak poststrukturalne analizy krytyczne cechuje znacznie większy radykalizm. Zorientowane są one bowiem na podważenie naukowości teorii rozwojowych (szczególnie koncepcji Piageta ${ }^{8}$ ) za ich - jak można by w duchu tej krytyki to określić - normalizacyjną propagandę i pseudonaukową mistyfikację (Newman, Holzman 2006). Na polu inicjowanych aksjologią humanistyczną sporów o rozwój jednostki pojawia się zatem nowy przedmiot krytyki: psychologia rozwojowa zorientowana na dziecko, która zbudowała i rozpowszechniła obraz rozwoju zamkniętego w paradygmacie stadiów, posiadających normalizujące charakterystyki.

Psychologowie poststrukturalni radykalnie odrzucają dominujący psychologiczny paradygmat, na którym oparta jest modernistyczna koncepcja rozwoju, a który nazywany jest przez nich przeciw-rozwojowym (anti-developmental). Rozwój w ujęciu modernistycznym (w okresie przed zwrotem interpretatywnym $\mathrm{w}$ metodologii nazywanym po prostu ujęciem naukowym) definiowany jest w niej jako zjawisko - jak piszą Newman i Holzman (2006) - obsesyjnie wiązane z ustalaniem punktów wyjścia, punktów dojścia i płynnego przejścia między nimi, tworząc w efekcie hierarchiczną i w swojej podstawowej istocie elitarną strukturę, która pozwala ustalać lokatę jednostki w rankingu i wytwarza model „idealnego dziecka” i ,idealnego dzieciństwa”. Poszukując alternatywnego ujęcia rozwoju, F. Newman i L. Holzman podkreślają konieczność odejścia od traktowania go jako wystandaryzowanego modelu na rzecz dostrzegania nie ilościowej, a przekształcającej natury przeżywania dzieciństwa i zdobywania nowych umiejętności oraz sposobów zachowań. W tym sensie, jak podkreślają, na przykład stawanie się człowiekiem mówiącym (becoming a speaker) nie jest po prostu nabywaniem umiejętności językowych, lecz

\footnotetext{
$8 \mathrm{~W}$ tym miejscu muszę poczynić ważne dla mnie zastrzeżenie. Akceptuję problematyzację medykalizujących ujęć w psychologii rozwojowej i pedagogice, opartych na „twardej” diagnostyce, fragmentaryzacji jednostki, ustalaniu norm rozwojowych dla arbitralnie przyjętych jako znaczące przejawów funkcjonowania i wytwarzających zabiegi korekcyjno-unifikujące. Przyznaję też, że koncepcja Piageta, która legła u podstaw wielu technik diagnostycznych, okazała się w tych obszarach dyskusyjna. Jednak w przeciwieństwie do poststrukturalnych psychologów wysoko cenię płynącą z Piagetowskiej teorii rozwoju sugestię o roli inicjowanej oddolnie przez dziecko wolnej eksploracji, pozbawionej interwencji dorosłego. Totalny atak na Piageta jest, w moim przekonaniu, wylewaniem dziecka z kąpielą.
} 
głęboko transformatywną, jakościową, intelektualną, emocjonalną, społeczną przemianą, która dostarcza nowych możliwości bycia w świecie i oddziaływania na niego.

Do Polski wciąż jeszcze nie dotarł kryzys psychologii rozwojowej, który wyraźnie zaznacza się na świecie co najmniej od lat osiemdziesiątych. Obecnie głos psychologów krytycznych jest wyraźnie słyszalny w zachodniej debacie nad dziećmi i dzieciństwem. Za przykład niech posłużą tu kanoniczne już prace Eriki Burman (2008) czy Johna R. Morssa (1995).

Odwołując się do tego, co Foucault nazywa praktykami dzielenia, które polegają na manipulacji łączącej naukę i praktyki wykluczenia, Dahlberg, Moss i Pence w pracy „Poza dyskursem jakości w instytucjach wczesnej edukacji i opieki. Języki oceny” (2103) podkreślają, że praktyki związane z posługiwaniem się teoriami rozwoju i umożliwiającymi klasyfikacje dzieci matrycami osiągnięć, „łatwo prowadzą do uprzedmiotowienia dzieci i nas samych jako badaczy. Dziecko staje się przedmiotem normalizacji, w czym pomaga wyrosła z psychologii rozwojowej pedagogika zorientowana na dziecko, której towarzyszy ocenianie rozwoju, stanowiące technologię normalizacji określającą, jakie powinno być dziecko. Elementem tego procesu staje się władza, oddziałująca poprzez tworzenie swojego rodzaju hierarchii między dziećmi, zbudowanej na podstawie tego, czy osiągnęły dane stadium, czy też nie. Spełnianie norm i zapobieganie odchyleniom od normy lub ich naprawianie zaczyna dominować nad praktyką pedagogiczną" (2013: 90).

Jak pisałyśmy z K. Gawlicz we wstępie do polskiego wydania tej książki, Dahlberg, Moss i Pence postulują radykalną zmianę sposobu myślenia o tym, czym wczesna edukacja i opieka mogą być, istotą tej zmiany czyniąc tytułowe „wyjście poza jakość”. Nie oznacza to rezygnacji z wysiłków na rzecz zapewnienia jak najlepszych warunków dla realizacji potencjału i indywidualnych zasobów dzieci i dobrego przeżywania przez nie dzieciństwa, ale odrzucenie pewnego dominującego sposobu rozumienia jakości edukacji, opartego na dostrzeżonej przez Foucaulta władzy ekspertów, narzucających definicję rozwoju i unifikację jego przejawów. Modernistycznie rozumiana jakość, zbudowana na odrzuceniu lokalnych kontekstów, powoduje, że zamiast jednostki i jej unikatowej biografii widzimy obiekt dyrektywnego kierowania i interwencyjnych korekt. Celem staje się redukcja różnorodności, a uzasadnieniem status eksperta. Siła zakorzenienia dyskursu jakości jest, zdaniem autorów, tak duża, że konieczne jest radykalne odrzucenie samego terminu i zmiana języka opisującego edukację i opiekę.

Tego rodzaju nowe podejście, polegające na tworzeniu pedag o g i k i mó wi ą c ej gło s e m d zi e cka (Dahlberg, Moss, Pence 2013), zakłada przede wszystkim postawę ciągłego pytania o znaczenie codziennej praktyki, nieustanne problematyzowanie jej, kwestionowanie i szukanie nowych rozwiązań. Praktyka, podejmowana w instytucjach takich jak żłobki, przedszkole i szkoła, przestaje być wdrożeniem i terenem diagnoz osiągania założonych, sfragmentaryzowanych celów, a staje się życiem.

„Z naszej postmodernistycznej perspektywy - piszą Dahlberg, Moss i Pence - nie ma czegoś takiego jak »dziecko« lub »dzieciństwo«, esencjalny byt czy stan, który należy odkryć, zdefiniować i wprowadzić w życie, tak, żebyśmy mogli powiedzieć innym i so- 
bie »oto, kim są dzieci; oto, czym jest dzieciństwo«. Zamiast tego istnieje wiele dzieci i wiele ujęć dzieciństwa, każde skonstruowane w oparciu o nasze »przekonania na temat tego, czym jest dzieciństwo oraz kim są i powinny być dzieci«. Zamiast czekać, aż nauka wyjawi nam, kim jest dziecko, musimy dokonywać wyborów dotyczących tego, kim jest ono według nas" (2013: 97).

Nawet jeśli wydać się to może nazbyt idealistyczne, przykłady takie, jak prężnie rozwijające się w całej Europie przedszkola Reggio Emilia (Karwowska-Struczyk 2012; Maj 2010), projekt sztokholmski (Dahlberg, Moss, Pence 2013: 193-220), czy wykorzystywanie teorii Foucaultowskiej w instytucjach dla małych dzieci (MacNaughton 2005), dowodzą, że jest to możliwe.

Zdaniem MacNaughton, dla poststruktralnych pedagogów, zajmujących się studiami nad wczesnym dzieciństwem, zasadniczym kierunkiem wyznaczającym refleksję i praktyki wokół dziecka jest przejście od jakości do aktywizmu rozumianego jako poszukiwanie rozwoju świadomości zorientowanej na dokonywanie transformacji na rzecz sprawiedliwości. To wyraźne w tym miejscu odniesienie do myśli P. Freire'a wskazuje na kluczową różnicę między byciem refleksyjnym a byciem refleksyjnym krytycznie (MacNaughton 2005: 6).

Teoria Foucaulta pozwala nam rozważać politykę prawdy, dlatego MacNaughton po refleksji wobec prawdy, czy raczej prawd, prezentuje prowadzoną z nauczycielami, a inspirowaną pracami Derridy, dekonstrukcję tekstów, które rządzą klasą szkolną i narzucają reżim prawdy o dziecku. To kolejny głos w sprawie konieczności zmiany języka. Do takich wymagających dekonstrukcji tekstów możemy zaliczyć teksty związane z programami wychowania i nauczania, książki dla dzieci, słowa piosenek, ale też poradniki metodyczne, przewodniki dla nauczycieli, kwestionariusze obserwacji dzieci, certyfikaty itd. Wszystkie one wytwarzają język, w którym mówi i w którym myśli nauczyciel.

Wykorzystywana przez MacNaughton analiza rizomatyczna (której źródłem są: Gilles Deleuse i Felix Gauttari), pozwala nauczycielom wyzwolić się z nieuświadamianych wcześniej założeń linearnej logiki i konstruować nowe rozumienie i tekstów, i zdarzeń.

Próby zastosowania teorii Foucaulta w praktyce (Reggio Emilia, projekt sztokholmski, projekty pracy z nauczycielami G. MacNaughton) są niezwykle frapujące. W sposób niespotykany wcześniej wyrażają się w nich nowe cechy pracy z dzieckiem, oparte na negacji diagnostycznej pewności i homogenizującej edukacji, i nowy język, który tę relację wytwarza.

\section{Od języka Rousseau do języka poststrukturalistów}

Cechy dyskursywne języka używanego $\mathrm{w}$ analizie dzieciństwa i dzieci, a nie jedynie jego formalnie ujmowana semantyka, prowadzą do zasadniczych różnic w rozumieniu dzieci i ich rozwoju oraz zasadniczo odmiennych praktyk kulturowych, które wobec dzieci są podejmowane. Gdyby podjąć wstępną próbę odszukania głównych cech języka Jana Jakuba Rousseau, które odróżniają go od języka poststrukturalistów, tworzących współcze- 
śnie alternatywną ofertę edukacyjną dla dzieci, jako ważne pola kontrastu można wskazać cztery pola wyróżnień:

- pewność versus niepewność rozstrzygnięć (różnicujące status nadawany tezom i projektom),

- uniwersalność versus lokalność (różnicujące zakładany zasięg rozumnych ustaleń),

- binarność versus różnorodność (różnicujący przyjęte założenia ontologiczne),

- instruktażowość versus deskryptywność (różnicujące postawę moralną).

Przyjrzyjmy się kolejno tym atrybutom. Po pierwsze, narracja Rousseau jest przepełniona poczuciem pewności. Chciałoby się powiedzieć, że Rousseau jest tym, który wie i zna wszystkie odpowiedzi. Swoim rozstrzygnięciom nadaje on wydźwięk ostateczny. Nawet tam, gdzie sam zauważa niespójności, mglistość czy wewnętrzne sprzeczności, przypisuje im ontyczny status tego, co miało być właśnie takie, a nie inne, i uznając, że w ten sposób jakakolwiek niepewność zostaje zniesiona.

Natomiast język poststrukturalnych praktyków używany jest jako nieustannie pytajny, niepewny, pozbawiony ostatecznych ustaleń i rozstrzygnięć. Budowany jest w logice prawd tymczasowych, prawd na próbę, choć tworzonych odpowiedzialnie i z najlepszą traktowaną jako równie chwilowa - wiedza.

Po drugie, w języku Rousseau (jego) opis rzeczywistości ma rangę opisu uniwersalnego, odnoszącego się do rzeczywistości ludzkiej jako takiej, wspólnej wszystkim. Definicja normalności oparta zostaje na tym, co - zdaniem Rousseau - naturalne (wychodzące z ręki Boga). Natura, jako wspólna wszystkim ludzkim istotom, czyni (jego) prawdę homogeniczną i jedną dla całej ludzkości.

Natomiast świat poststrukturalnej edukacji oparty jest na definicjach z założenia lokalnych. To odpowiada zasadniczym inspiracjom Foucaultowskim i stanowi źródło zakwestionowania uniwersalizujących roszczeń „Świata Mniejszości” formułowanych wobec „posiadania Prawdy”. Lokalność, kontekstowość, indywidualizacja - tworzą podstawową zasadę nadawania znaczeń każdorazowo negocjowanych społecznie.

Po trzecie, Rousseau nie ustrzegł się typowej dla świata zachodniego binarności. Dwubiegunowe kategoryzacje, porządkujące nasze myślenie przeciwieństwa i antynomie dają się w Emilu odnaleźć znacznie bardziej niż w innych pracach Rousseau. Natura jest przeciwstawiona kulturze, zbawienna dzikość zdeprawowanej kulturze, a chłopcy dziewczętom. Również dzieci (przeciwstawione dorosłym) są w wyniku zachowań osób z ich otoczenia naturalne lub zepsute, nadwrażliwe lub opanowane, rozpieszczone lub zahartowane, powściągliwe lub nieopanowane?

W odróżnieniu od niego język postruktrukturalnych edukatorów poszukuje różnorodności, rozmytych granic i pluralizmu. Zniesienie wyrazistej linii demarkacyjnej między

9 Na marginesie - z pewnym wstydem - zauważę, że zestawienia języka Rousseau i poststrukturalistów dokonuję ni mniej ni więcej tylko w modelu modernistycznie binarnym. 
tym, co uznane za normalne, i tym, co za takie uznawane nie jest, prowadzi do otwarcia się na bogactwo wielorakości. Dzieci ukazują się nie w zróżnicowaniu wertykalnym, rangowym, lecz horyzontalnym. Jeśli przypomnimy sobie casus dziecka, które - zgodnie z założeniami Rousseau - ma opanowywać swoje emocje i płacz z chwilą wzrostu sprawności językowej, to warto tu dla kontrastu przywołać MacNaughton, która dekonstruuje dualizm: ,niekontrolowane emocje jako nienormalne w porównaniu z »dorosłymi« emocjami”, ukazując jego epistemologiczną przynależność do świata zachodniego (2005: s. 83-84).

I wreszcie po czwarte, w konsekwencji trzech pierwszych cech język Emila jest językiem instrukcji. Jeśli Rousseau wie, jaka jest rzeczywistość, wie, co jest normalne i wie, jak to działa w warunkach społecznych, nie dziwi fakt jego normatywnych zaleceń.

Poststrukturalni nauczyciele rezygnują z formułowania instrukcji. Ich język jest językiem opisu (opisu zdarzeń, zachowań, sytuacji, własnych myśli i decyzji). W miejsce tekstów projektujących, w miejsce planów i kryteriów ocen stopnia ich wdrożenia oraz pomiaru efektów mamy narracje, dzienniki obserwacji, portfolia na wzór tych, o których piszą Dahlberg, Moss, Pence (2013). W miejsce diagnoz i wskaźników dziecku zaczyna towarzyszyć jego historia, konstruowana przez uważnego i zaciekawionego bogactwem dziecięcych osobowości i charakterów nauczyciela.

W Polsce nurt pedagogiki dzieciństwa i wczesnej edukacji, zainspirowany myślą poststrukturalistyczną i krytyczną, jest słabo opracowany, a nierzadko w ogóle nieznany. Status normalizującego paradygmatu psychologii rozwojowej i budowanych na jej podstawie standardów nie tylko ma się dobrze, ale jest systematycznie wzmacniany i traktowany jako postępowy. Pomiar - diagnoza - terapia to triada, która w odczuciu społecznym dowodzi, że dziecko otrzymuje wsparcie. Również w obszarze proponowanych alternatyw edukacyjnych osiągnęliśmy stan, który można określić jako koncepcja „nowości wiecznie żywej", która polega na nieustannym przywoływaniu projektów historycznych (np. pedagogiki Marii Montessori, Celestyna Freineta, Szkoły Waldorfskiej Rudolfa Steinera, Planu Daltońskiego itd.) jako nowatorskich opcji. I rzecz nie w tym, że odmawiam tym rozwiązaniom wartości. Przeciwnie, zaliczam je do znakomitego dorobku pedagogiki i kultury. Ale niepokoi fakt poststrukturalnej ciszy w miejscach, gdzie przedmiotem debaty są dzieci i instytucje, w których przeżywają swoje dzieciństwo.

Polskie dzieci pozostają w twardej władzy tak zwanych ekspertów, poddawane czujnej obserwacji ze strony dorosłych, konstruowane dla spełnienia wystandaryzowanych kryteriów i poddane diagnostyczno-wyrównawczej trosce, jakiej nie zaakceptowałaby żadna inna grupa wiekowa.

\section{Literatura}

Baczko B. (2009), Rousseau - samotność i wspólnota. Gdańsk, Wydawnictwo słowo/obraz terytoria. 
Bowbly J. (2007), Przywiązanie. Thum. M. Polaszecka-Nicke. Warszawa, Wydawnictwo Naukowe PWN.

Burman E.(2008), Deconstructing Developmental Psychology. Second edition. London, Routledge.

Carr W., Kemmis S. (1986), Becoming Critical: Education, Knowledge, and Action Research. New York, Routledge, Falmer Press.

Dahlberg G., Moss P., Pence A. (2013), Poza dyskursem jakości w instytucjach wczesnej edukacji i opieki. Języki oceny. Tłum. K. Gawlicz. Wrocław, Wydawnictwo Naukowe Dolnośląskiej Szkoły Wyższej.

Erikson E. (2004), Tożsamość a cykl życia. Tłum. M. Żywicki. Poznań, Zysk i S-ka Wydawnictwo.

Escobar A. (1991), Planning, W: W. Sachs (ed.), The Development Dictionary: A Guide to Knowledge as Power. London, Zed Books.

Freire P. (1975), Cultural Action for Freedom. Harmondsworth, Penguin.

Freire P. (1983), Pedagogy of the Oppressed. New York, Continuum.

Gutman H. (1988), Rousseau's Confessions: A Technology of the Self. W: L.H. Martin, H. Gutman, P.H. Hutton (eds.), Technologies of the self. Amherst: University of Massachuset. Dostępne na: http://www.thinkingtogether.org/rcream/archive/Old/F2002/Gutman.pdf.

Hicks R.C. (2004), Explaining postmodernism. Scepticism and Socialism from Rousseau to Foucault. Tempe, New Berlin, Scholargy Publishing.

Johnson P. (1988), Intelektualiści. Tłum. A. Piber, Poznań, Zysk i Spółka Wydawnictwo.

Karwowska-Struczyk M. (2012), Edukacja przedszkolna. W poszukiwaniu innych rozwiazań. Warszawa, Wydawnictwo Uniwersytetu Warszawskiego.

Klus-Stańska D. (2013), Myślenie poza diagnozq i ewaluacją. Pytanie o możliwość zmiany logiki tworzacej edukację. „Człowiek - Teraźniejszość - Edukacja”, 4(64).

Klus-Stańska D. (w druku, a), Odwrót od rozwoju: kontrowersyjna czy obiecująca zmiana paradygmatu wczesnej edukacji. „Studia Edukacyjne”.

Klus-Stańska D. (w druku, b), Wyjść poza instytucjonalna standaryzację dziecka. Nowe inspiracje teoretyczne dla wczesnej edukacji. „Studia Pedagogiczne”.

Kohlberg L., Mayer R. (1993), Rozwój jako cel wychowania. W: Z. Kwieciński, L. Witkowski (red.), Spory o edukację. Warszawa, IBE.

Legowicz J. (1955), Wstęp. W: J.J. Rousseau, Emil, czyli o wychowaniu. Wrocław Zakład im. Ossolińskich, Wydawnictwo PAN.

MacNaughton G. (2005), Doing Foucault in Early Childhood Studies. Applying poststructural ideas. Routledge, London - NY.

Maj A. (2010), Koncepcja edukacji przedszkolnej w Reggio Emilia we Włoszech. W: Z. Melosik, B. Śliwerski (red.), Edukacja alternatywna w XXI wieku. Poznań-Kraków, Oficyna Wydawnicza „Impuls”.

Marshall J.D. (1996), Michel Foucault: Personal Autonomy and Education. Kluwer Academic Publishers.

Moss-Kanter R. (1972), The Organization Child: Experience Management in a Nursery School. „Sociology of Education”, 45.

Morss, J. (1996), Growing Critical: Alternatives to Developmental Psychology, London: Routledge.

Newman F., Holzman L. (2006), Unscientific Psychology: A Cultural-performatory Approach to Understanding Human Life. Lincoln, NE, iUniverse Inc.

Renz-Polster H. (2012), Zrozumieć dzieci. Jak kształtuje nasze dzieci ewolucja. Tłum. J. Kurkiewicz-Laskowska. Poznań, Media Rodzina. 
Rousseau J.J. (1955), Emil, czyli o wychowaniu. T. 1. Tłum. W. Husarski. Wrocław, Ossolińskich, Wydawnictwo PAN.

Schoenebeck H. (1994a), Antypedagogika: być i wspierać zamiast wychowywać. Tłum. M. Szymańska. Warszawa, Jacek Santorski \& CO. Agencja Wydawnicza.

Schoenebeck H. (1994b), Antypedagogika $w$ dialogu: wprowadzenie $w$ rozmyślanie antypedagogiczne. Tłum. D. Sztobryn, Kraków, Oficyna Wydawnicza „Impuls”.

Spaemann R. (2011), Rousseau - człowiek czy obywatel. Dylemat nowożytności. Tłum. J. Merecki. Warszawa, Oficyna Naukowa.

Szkudlarek T., Śliwerski B. (1992), Wyzwania pedagogiki krytycznej i antypedagogiki. Kraków, Oficyna Wydawnicza „Impuls”.

Śliwerski B. (2007), Pedagogika dziecka - studium pajdocentryzmu. Gdańsk, Gdańskie Wydawnictwo Psychologiczne.

Witkowski L., Giroux H. (2010), Edukacja i sfera publiczna. Kraków, Oficyna Wydawnicza Impuls. 